\title{
Determination and Distribution of Lanthanoids in Hard Tissue (Shell and Pearl) of Shellfish by ICP-MS
}

\author{
Osamu Fujino and Eriko Terada \\ Research Institute for Science and Technology, Kinki University, \\ Kowakae, Higashiosaka 577, Japan
}

\begin{abstract}
Lanthanoid elements in hard tissue (shell and pearl) of shellfish were determined and their distributions were examined by ICP-MS. The ICP-MS signals for lanthanoids contained in these samples were highly suppressed by coexisting calcium, the macro-component, which made the determination of lanthanoids difficult. To resolve this problem, we applied the coprecipitation method with ferric hydroxide to separate the lanthanoids from the interfering element, calcium. All the lanthanoids were coprecipitated quantitatively and separated at pH 9. Pearl and shell samples were dissolved in inorganic acids and filtered, then the 14 lanthanoid elements in the sample solution were simultaneously determined. The lanthanoids contents in hard tissues ranged from 0.25 to $82 \mathrm{ppb}$ in Akoya-gai of seawater shellfish, and from 0.3 to $72 \mathrm{ppb}$ in the Ikecho-gai of Lake Biwa. It was found that the distribution of lanthanoid elements in these samples followed the Oddo and Harkins law.
\end{abstract}

Keywords Lanthanoid elements, inductiveiy coupled plasma mass spectrometry, shellfish, coprecipitation, ferric hydroxide

The main inorganic component of hard tissues is calcium phosphate ${ }^{1}$ for bones and teeth, and calcium carbonate for corals, shell and pearl. We have taken great interest in the contents and distribution of microcomponent elements in these natural samples ${ }^{2-4}$ which contained a large quantity of calcium as macrocomponent. And in laboratory system, the distribution behavior of the trace ions between these calcium precipitation ${ }^{5,6}$ and aqueous solution phase was studied.

Since information concerning lanthanoide behavior under the natural environment is very scarce ${ }^{7-9}$, we have attempted determination of lanthanoid elements in natural samples such as seawater and minerals by ICPAES and activation analysis method. However, determination of many elements had been difficult because of the lack of the equipment sensitivity and the limitation in the chemical processing of preconcentration.

Accordingly, we adopted the rapidly advanced inductively coupled plasma-mass spectrometry (ICPMS) method ${ }^{10,11}$ which enables super-sensitive and simultaneous determination of a number of elements. We report simultaneous determination by ICP-MS of 14 lanthanoid elements by ICP-MS and their distribution in hard tissues of seawater Akoya-gai, the mother shellfish of cultured pearl, and Ikecho-gai in inland water.

\section{Experimental}

Apparatus and reagents

The instrumentation employed was a Shimadzu Model
PIMS-3000 inductively coupled plasma mass spectrometer. The instrumental condition and isotope measured for lanthanoid elements are shown in Tables 1 and 2, respectively. The ICP-AES instrumentation was a Jarrell-Ash Model 575 type with a $0.75 \mathrm{~m}$ focal length Czerny-Turner, holographic grating, 1800 grooves $/ \mathrm{mm}$ and a cross flow type nebulizer. Slit widths are: entrance $10 \mu \mathrm{m}$ and exit $10 \mu \mathrm{m}$. The gas flow rate $(1 / \mathrm{min})$ were: coolant 14; auxiliary 1.2; carrier 1.5 .

All the reagents used have been described elsewhere. ${ }^{10}$

\section{Procedure}

Since the Akoya pearls we sampled from the Ago Bay in Mie Prefecture are cultured, pearl cores needed to be separated from the pearl layer on each surface. As each pearl layer is very tough and hard to peel off, we used pliers to put pressure on the pearl layer and separate it from the pearl core. The pearl and shell of these Akoyagai and Ikecho-gai were soaked in pure water for a whole day, and washed several times with pure water. Dried at $100^{\circ} \mathrm{C}$ for one hour and cooled down, they were crushed and reduced to powder in a mortar. The sample was measured in a beaker and mixed with nitric acid, hydrochloric acid and perchloric acids, then the cycle of heating and drying was repeated a few times on an electric hot plate. After cooling, the sample solution was filtered with No. $5 \mathrm{c}$ paper. We diluted the filtrate with pure water to make up a $100 \mathrm{ml}$ sample solution.

A sample solution of 0.2 to $4 \mathrm{~g}$ as sample weight was put in a beaker and $3 \mathrm{mg}$ of iron was added to it. Sodium hydroxide was used to adjust it at $\mathrm{pH} 9$ and it 
Table 1 ICP-MS operating conditions

\begin{tabular}{lc}
\hline RF power & $1.4 \mathrm{~kW}$ \\
Carrier gas flow rate & $1.11 / \mathrm{min}$ \\
Auxiliary gas flow rate & $1.41 / \mathrm{min}$ \\
Coolant gas flow rate & $161 / \mathrm{min}$ \\
Solution uptake rate (with pumping) & $1.2 \mathrm{ml} / \mathrm{min}$ \\
Sampling cone & $1 \mathrm{~mm}$ \\
Skimmer cone & $1 \mathrm{~mm}$ \\
Dwelling time & $100 \mathrm{~ms}$ \\
Number of sweeps & 10 \\
Integration time & $1 \mathrm{~s} / \mathrm{amu}$ \\
\hline
\end{tabular}

Table 2 Isotopes measured

\begin{tabular}{ccc}
\hline Element & Mass number & Abundance, \% \\
\hline La & 139 & 99.9 \\
Ce & 140 & 88.5 \\
Pr & 141 & 100 \\
Nd & 146 & 17.2 \\
Sm & 147 & 15.0 \\
Eu & 151 & 47.8 \\
Gd & 157 & 15.7 \\
Tb & 159 & 100 \\
Dy & 163 & 24.9 \\
Ho & 165 & 100 \\
Er & 167 & 26.8 \\
Tm & 169 & 100 \\
Yb & 172 & 21.9 \\
Lu & 175 & 97.4 \\
\hline
\end{tabular}

precipitated as ferric hydroxide. The solution was filtered, and the precipitate was dissolved in hydrocloric acid. After it dried up, we added hydrochloric acid and pure water to make up a $20 \mathrm{ml}$. Also, we added indium ${ }^{11}$ to obtain $100 \mathrm{ppb}$ concentration for adjusting the interference of inorganic acids and ferric ions.

\section{Results and Discussion}

Sensitivity and calibration curve

As we have already reported, the elements sensitivity, in ICP-MS adopted in this study, ranged from ca. $0.002 \mathrm{ppb}$ to $0.07 \mathrm{ppb}$. Relative standard deviation (RSD) of measured intensity for 10 replicate measurements of 10,1 and $0.1 \mathrm{ppb}$ solution of europium under operating condition in Table 1 were $1.3,2.4$ and $9.6 \%$, respectively. However, RSD exceeded more than $30 \%$ for $0.04 \mathrm{ppb}$ or less solution. Other lanthanoid elements showed tendencies similar to that of europium. Clear repeatability falled dramatically over the range less than 10 ppt.

Accordingly, a calibration curve was created between 0.1 to $5 \mathrm{ppb}$ because the intensity is proportional to the concentration in this ranges.

Effect of coexisting substances

[Effect of hydrochloric acid concentrations]

After the decomposition of shell, lanthanoid elements were separated from excess calcium by ferric hydroxide as mentiond below and the iron precipitate was dissolved with hydrochloric acid.

The effects of hydrochloric acid concentration in a range from 0.001 to $1 \mathrm{~mol} / \mathrm{dm}^{3}$ on the intensity for lanthanoids were studied. The results obtained for lanthanum, europium and lutetium are shown in Table 3 as a typical example. Table 3 shows that negative interference occurred at a hydrochloric acid level of $0.03 \mathrm{~mol} /$ $\mathrm{dm}^{3}$, and as the concentration increased, the interference became nore severe. Other lanthanoid elements showed similar tendencies to those in Table 3. To suppress such interference, we took an internal standardization method with indium. ${ }^{11}$ As seen in Table 3, we were able to depress almost all these interferences.

[Effect of a large amount of calcium ion]

The major component of pearls and shells is calcium which is contained $10^{5}$ to $10^{7}$ times excess with respect to lanthanoids. Here, the effect of coexisting calcium at

Table 3 Effect of hydrochloric acid concentrations on measured and corrected values of lanthanoids (ppb)

\begin{tabular}{|c|c|c|c|c|c|c|}
\hline \multirow{2}{*}[\mathrm{HCl}]{$/ \mathrm{mol} \mathrm{dm}^{-3}$} & \multicolumn{2}{|c|}{ La } & \multicolumn{2}{|c|}{$\mathrm{Eu}$} & \multicolumn{2}{|c|}{$\mathbf{L u}$} \\
\hline & $C_{\text {meas }}$ & $C_{\text {cor }}$ & $C_{\text {meas }}$ & $C_{\text {cor }}$ & $C_{\text {meas }}$ & $C_{\text {cor }}$ \\
\hline 0.001 & 1.0 & 1.0 & 1.0 & 1.0 & 1.0 & 1.0 \\
\hline 0.003 & 1.03 & 0.99 & 1.01 & 1.05 & 0.94 & 0.97 \\
\hline 0.01 & 1.04 & 1.02 & 0.95 & 0.97 & 1.01 & 0.96 \\
\hline 0.03 & 0.87 & 0.99 & 0.88 & 0.98 & 0.89 & 0.98 \\
\hline 0.06 & 0.89 & 1.04 & 0.91 & 1.01 & 0.89 & 1.05 \\
\hline 0.10 & 0.83 & 1.02 & 0.84 & 1.02 & 0.78 & 0.99 \\
\hline 0.30 & 0.68 & 0.92 & 0.67 & 0.94 & 0.73 & 1.02 \\
\hline 0.60 & 0.66 & 1.02 & 0.69 & 1.03 & 0.62 & 0.98 \\
\hline 1.00 & 0.64 & 0.94 & 0.64 & 0.99 & 0.62 & 1.02 \\
\hline
\end{tabular}

$C_{\text {meas: }}$ measured concentration; $C_{\text {cor }}$ : concentration which is corrected by indium internal standardization for the compensation of the hydrochloric acid interference. 
Table 4 Effect of calcium ion concentration on measured values of lanthanoids (ppb)

\begin{tabular}{clllll}
\hline $\mathrm{Ca} / \mathrm{mg} \mathrm{ml}^{-1}$ & $\mathrm{La}$ & $\mathrm{Nd}$ & $\mathrm{Eu}$ & $\mathrm{Ho}$ & $\mathrm{Lu}$ \\
\hline 0 & 1.0 & 1.0 & 1.0 & 1.0 & 1.0 \\
0.1 & 1.01 & 0.98 & 1.03 & 0.94 & 0.98 \\
0.3 & 0.86 & 0.96 & 0.85 & 0.88 & 0.85 \\
0.7 & 0.68 & 0.75 & 0.55 & 0.63 & 0.59 \\
1.0 & 0.50 & 0.48 & 0.41 & 0.53 & 0.41 \\
3.0 & 0.089 & 0.067 & 0.1 & 0.12 & 0.074 \\
7.0 & 0.071 & 0.050 & 0.04 & 0.073 & 0.055 \\
10.0 & 0.053 & 0.049 & 0.02 & 0.04 & 0.037 \\
30.0 & 0.035 & 0 & 0 & 0 & 0 \\
70.0 & 0.09 & 0.02 & 0 & 0.07 & 0.074 \\
\hline
\end{tabular}

concentrations of 0.1 to $70 \mathrm{mg} / \mathrm{ml}$ on the intensity for $1 \mathrm{ppb}$ lanthanoid elements was studied. The result for various elements is shown in Table 4. As the calcium concentration increases, intensity of lantanoids decreased at a higher concentration of calcium ions, and lanthanoids could not be detected at concentrations of calcium more than $3 \mathrm{mg} / \mathrm{ml}$. The results for other lanthanoid elements were similar to those in Table 4. Therefore, a separation of the elements from the large amount of calcium in pearls and shells was necessary before measuring by ICP-MS.

[Effect of coexisting elements]

We made a thorough analysis and have already reported on mutual interference of coexistent elements in lanthanoids measurement. ${ }^{10}$ Based on these data, the study on interference of coexisting elements with lanthanoids in pearls and shells was conducted. As a result, it was observed that monoxide ions of praseodymium(141) interferes with gadolinium(157) ion between 10 to $20 \%$ in the actual sample.

As it has been already reported ${ }^{10}$, the adjustment of interference was conducted as follows. First, we measured intensities at mass of 157 of the actual sample solution $\left(I_{\mathrm{Gd}+\mathrm{PrO}}\right)$, and the praseodymium solution $\left(I_{\mathrm{PrO}}\right)$, the concentration of which was known $\left(C_{\mathrm{Pr}}\right)$. Then, the concentration of praseodimium $\left(S_{\mathrm{Pr}}\right)$ in the actual sample was determined by measuring intensities at mass number of $141\left(S_{\mathrm{Pr}}\right)$ of 141 of both solutions. With these data, the actual $\mathrm{Gd}$ intensity $\left(I_{\mathrm{Gd}}\right)$ at mass number of 157 in the sample was calculated from the following formula.

$$
I_{\mathrm{Gd}}=I_{\mathrm{Gd}+\mathrm{PrO}}-I_{\mathrm{PrO}} \times S_{\mathrm{Pr}} / C_{\mathrm{Pr}}
$$

\section{Coprecipitation separation with ferric hydroxide}

Since the interference of calcium with lanthanoids determination was very serious, we applied the coprecipitation method with ferric hydroxide to separation of lanthanoids from a large amount of coexisting calcium. First, each lanthanoide was coprecipitated in the $20 \mathrm{ml}$ solution by ferric ions $(1 \mathrm{mg})$ and filtered. The precipitation was dissolved by hydrochloric acid, then water was added to make up a $20 \mathrm{ml}$ solution. The solution was measured by ICP-MS. The correlation between coprecipitation rate of lanthanoids and $\mathrm{pH}$ of solution ranging from 2 to 10 which was sufficient for the formation of precipitation, is shown in Table 5 . In the solutions under $\mathrm{pH} 7$, little lanthanoids coprecipitation was seen, but most elements except for lanthanum and cerium coprecipitated quantitatively at $\mathrm{pH} 8$, and the coprecipitation rate exceeded $95 \%$ at $\mathrm{pH} 9$ or up.

Moreover, the dependences of coprecipitation rate of lanthanoids on the amount of iron ranging from 1 to $5 \mathrm{mg}$ and on the solution volume ranging from 10 to $100 \mathrm{ml}$ were studied. Under these conditions, all lanthanoids were quantitatively coprecipitated and calcium was not coprecipitated at all.

Effect of ferric ion cocentration on intensity of lanthanoids

Ferric hydroxide used as a precipitant, which was dissolved by hydrochloric acid as well as lanthanoids, was introduced directly into ICP-MS equipment. The effect of concentrations of ferric ion on ICP-MS inten-

Table 5 Coprecipitation percent of lanthanoids with ferric hydroxide at various pH solutions

\begin{tabular}{|c|c|c|c|c|c|c|c|c|c|}
\hline \multirow{2}{*}{ Element } & \multicolumn{9}{|c|}{$\mathrm{pH}$} \\
\hline & 2 & 3 & 4 & 5 & 6 & 7 & 8 & 9 & 10 \\
\hline La & 0 & 0 & 0 & 0 & 19.6 & 10.9 & 59.6 & 88.2 & 93.8 \\
\hline $\mathrm{Ce}$ & 0 & 0 & 0 & 2.4 & 41.7 & 42.5 & 82.6 & 96.5 & 96.2 \\
\hline Pr & 0 & 0 & 0 & 3.9 & 61.3 & 48.7 & 89.0 & 99.8 & 97.2 \\
\hline Nd & 4.4 & 5.7 & 8.9 & 11.1 & 66.2 & 50.3 & 89.3 & 101 & 103 \\
\hline $\mathrm{Sm}$ & 1.2 & 3.8 & 7.3 & 14.5 & 77.0 & 62.1 & 94.7 & 98.5 & 98.8 \\
\hline $\mathrm{Eu}$ & 0 & 0 & 0 & 0.2 & 72.1 & 59.4 & 94.5 & 95.2 & 94.6 \\
\hline Gd & 0 & 0 & 0 & 0 & 64.5 & 46.8 & 95.0 & 96.8 & 95.5 \\
\hline $\mathbf{T b}$ & 2.9 & 1.6 & 3.3 & 10.3 & 70.3 & 62.9 & 95.2 & 95.3 & 97.6 \\
\hline Dy & 3.1 & 2.5 & 5.9 & 9.7 & 70.5 & 60.5 & 97.6 & 98.7 & 95.5 \\
\hline Ho & 1.9 & 0 & 5.1 & 9.7 & 69.1 & 60.5 & 94.8 & 99.8 & 93.6 \\
\hline $\mathrm{Er}$ & 0 & 0.1 & 5.9 & 11.6 & 70.8 & 58.7 & 97.4 & 96.3 & 96.7 \\
\hline $\mathrm{Tm}$ & 0 & 0 & 0.8 & 8.9 & 73.8 & 68.9 & 97.6 & 95.2 & 99.2 \\
\hline $\mathrm{Yb}$ & 0 & 0 & 0 & 8.8 & 76.7 & 72.8 & 97.0 & 99.2 & 98.7 \\
\hline $\mathrm{Lu}$ & 0 & 0 & 0 & 1.7 & 70.0 & 68.5 & 98.6 & 98.8 & 99.8 \\
\hline
\end{tabular}


Table 6 Effect of ferric ion concentration on measured and corrected values of lanthanoids (ppb)

\begin{tabular}{rllllllll}
\hline \multirow{2}{*}{ Fe(ppm) } & \multicolumn{2}{c}{$\mathrm{La}$} & & \multicolumn{2}{c}{ Eu } & & \multicolumn{2}{c}{ Lu } \\
\cline { 2 - 3 } \cline { 7 - 8 } \cline { 7 - 8 } & $C_{\text {meas }}$ & $C_{\text {cor }}$ & & $C_{\text {meas }}$ & $C_{\text {cor }}$ & & $C_{\text {meas }}$ & $C_{\text {cor }}$ \\
\hline 0 & 1.0 & 1.0 & & 1.0 & 1.0 & & 1.0 & 1.0 \\
10 & 0.92 & 0.95 & & 0.97 & 0.99 & & 0.89 & 1.05 \\
70 & 0.87 & 1.02 & & 0.88 & 1.00 & & 0.87 & 1.02 \\
100 & 0.83 & 1.03 & & 0.78 & 1.02 & & 0.80 & 0.96 \\
300 & 0.65 & 0.98 & & 0.67 & 0.98 & & 0.67 & 1.01 \\
500 & 0.54 & 1.01 & & 0.56 & 1.01 & & 0.56 & 0.98 \\
\hline
\end{tabular}

$C_{\text {meas: }}$ measured concentration; $C_{\text {cor }}$ : concentration which is corrected by indium internal standardization for the compensation of the ferric ion interference.

sities for lantanoids was studied. The result is shown in Table 6. Every element was affected by ferric ion concentrations. Then, the use of indium as an internal standard, which was applied to the correction of hydrochloric acid interference, depressed these interferences. Therefore, the direct measurement and determination of elements were possible without separation of elements from ferric ions coexisting by the coprecipitation method.

\section{Determination and distribution of lanthanoids in pearl and shell}

It is necessary to grasp not only the quantity of a large amount of calcium and other major elements but also distributions of these elements in pearl and shell. Qualitative and quantitative analysis of these samples was carried out by ICP-AES. The results are shown in Table 7. Alkaline-earth metal and alkali metal elements contained in seawater and fresh water to a considerable amount, were also contained in shells and pearls. On the other hand, contents of iron and manganese are very low ppb order in seawater but are remarkably high in shells and pearls. We especially noted the high concentration of manganese in hard tissue of Ikecho-gai.

As stated above, it is reasonable to think that the hard tissue contains the inorganic elements shown in Table 7 and several $\%$ of organic compound.

The main purpose of this study is to analyze lanthanoids, thus we determined these elements more precisely. In the analysis of an actual sample by ICPMS, the sample amount to be measured may affect the determination value. Therefore, samples were taken from the pearl sample solution, as weight of sample from 0.149 to $3.87 \mathrm{~g}$. We added $3 \mathrm{mg}$ of iron ions to each sample, then carried out the pre-processing procedures of measurement. From obtained data, it was found that RSD of determined values for five samples, including the fluctuation due to the pre-processing, were between 10 to $20 \%$. The analytical results of 14 lanthanoid elements in shells and pearl of Akoya-gai and Ikecho-gai are shown in Table 8. As a comparison, lanthanoid concentrations in seawater and fresh water were tabulated in the table. ${ }^{12}$

The lanthanoid contents in the shell and pearl of Akoya-gai and Ikecho-gai from $0.25 \mathrm{ppb}$ for thulium to $82 \mathrm{ppb}$ for cerium, are overall very low. Also, lanthanoid contents were greatly dependent on their atomic numbers, showing that contents of elements with smaller atomic number (light elements group) were relatively higher than those of elements with larger atomic number (heavy elements group). Moreover, the distribution of these elements in seawater did not follow the OddoHarkins law ${ }^{13,14}$, that is, contents of elements with even atomic numbers are greater than those of the elements with the odd atomic numbers before and after. However, lanthanoid elements in shell and pearls producted with soft tissue of shell followed the law such as the crust of the earth, mineral and soil. ${ }^{15}$

Now we discuss the correlation between contents of elements contents and habitat of environmental samples. Based on the values presented in Table 8, concentration ratios of lanthanoids in hard tissues to those in sea or flesh water were calculated. The calculation result is tabulated in Table 8. Although the lanthanoid concentrations in seawater were considerably lower than those in fresh water, their contents in hard tissues of Akoya-gai and Ikecho-gai were the same level. Therefore, as shown in Table 9, lanthanoids were concentrated to $10^{3}-10^{5}$ times in Akoya-gai and $10^{1}-10^{3}$ times in Ikecho-gai, with various concentration ratios. These concentration ratios indicate that concentrations of lanthanoids with smaller atomic numbers, i.e., with larger ionic radii, were relatively high. In addition, we found another interesting fact that both the content and the concentration ratio of ytterbium were remarkably high in pearls. It seems that the soft tissue such as the

Table 7 Contents of macro-component elements (ppm) in pearl and shell

\begin{tabular}{ccccccccc}
\hline Sample & $\mathrm{Ca}$ & $\mathrm{Mg}$ & $\mathrm{Sr}$ & $\mathrm{Ba}$ & $\mathrm{Na}$ & $\mathrm{K}$ & $\mathrm{Fe}$ & $\mathrm{Mn}$ \\
\hline Ikecho-gai & & & & & & & & \\
$\quad$ Shell & $3.84 \times 10^{5}$ & 15.7 & 424 & 38.2 & 2026 & 60.7 & 106 & 894 \\
$\quad$ Pearl & $3.75 \times 10^{5}$ & 40.2 & 477 & 62.3 & 1634 & - & 45.3 & 1015 \\
Akoya-gai & & & & & & & & \\
$\quad$ Shell & $3.72 \times 10^{5}$ & 609 & 883 & 1.0 & 4208 & 171 & 36.8 & 59.7 \\
Pearl & $3.27 \times 10^{5}$ & 648 & 954 & 2.3 & 8160 & 202 & 27.6 & 25.4 \\
\hline
\end{tabular}


Table 8 Analytical results and distribution of lanthanoids in pearl and shell

\begin{tabular}{|c|c|c|c|c|c|c|}
\hline \multirow[b]{2}{*}{ Element } & \multicolumn{3}{|c|}{ Akoya-gai (Pearl oyster) } & \multicolumn{3}{|c|}{ Ikecho-gai (Freshwater pearl mussel) } \\
\hline & $\begin{array}{l}\text { Shell, } \\
\text { ppb }\end{array}$ & $\begin{array}{l}\text { Pearl, } \\
\text { ppb }\end{array}$ & $\begin{array}{l}\text { Concentration in sea water }{ }^{13}, \\
\qquad 10^{3} \mathrm{ppb}\end{array}$ & $\begin{array}{l}\text { Shell, } \\
\text { ppb }\end{array}$ & $\begin{array}{c}\text { Pearl, } \\
\text { ppb }\end{array}$ & $\begin{array}{l}\text { Concentration in fresh water }{ }^{13}, \\
\qquad 10^{2} \mathrm{ppb}\end{array}$ \\
\hline${ }^{57} \mathbf{L a}$ & 61 & 50.6 & 5.6 & 40 & 6.5 & 20 \\
\hline${ }^{58} \mathrm{Ce}$ & 82 & 53 & 1.3 & 72 & 11 & 6 \\
\hline${ }^{59} \mathrm{Pr}$ & 23 & 7.7 & 0.7 & 7.2 & 1.6 & 3 \\
\hline${ }^{60} \mathrm{Nd}$ & 42 & 29.9 & 3.6 & 38 & 6.8 & 20 \\
\hline${ }^{62} \mathrm{Sm}$ & 10 & 5.2 & 0.63 & 7.6 & 3.1 & 3 \\
\hline${ }^{63} \mathrm{Eu}$ & 2.6 & 1.1 & 0.18 & 1.5 & 1.1 & 0.7 \\
\hline${ }^{64} \mathrm{Gd}$ & 13 & 6.4 & 1.3 & 8.9 & 3.5 & 7 \\
\hline${ }^{65} \mathrm{~Tb}$ & 2.8 & 1.0 & 0.14 & 1.3 & 0.6 & 0.8 \\
\hline${ }^{66} \mathrm{Dy}$ & 16 & 3.6 & 1.5 & 7.0 & 1.5 & 5 \\
\hline${ }^{67} \mathrm{Ho}$ & 1.8 & 0.71 & 0.31 & 1.0 & 0.4 & 1 \\
\hline${ }^{68} \mathrm{Er}$ & 7.8 & 2.2 & 1.3 & 4.1 & 1.4 & 5 \\
\hline${ }^{69} \mathrm{Tm}$ & 0.72 & 0.25 & 0.2 & 0.65 & 0.3 & 0.9 \\
\hline${ }^{70} \mathrm{Yb}$ & 8.6 & 16.6 & 1.2 & 3.2 & 16.1 & 5 \\
\hline${ }^{71} \mathrm{Lu}$ & 0.81 & 0.64 & 0.19 & 0.8 & 0.7 & 0.8 \\
\hline
\end{tabular}

Table 9 Concentration ratio of lanthanoids in hard tissues of shellfishes to those in sea and fresh water

\begin{tabular}{ccccc}
\hline \multirow{5}{*}{ Element } & $\begin{array}{c}\text { Shell/Sea- } \\
\text { water } \\
\left(\times 10^{3}\right)\end{array}$ & $\begin{array}{c}\text { Pearl/Sea- } \\
\text { water } \\
\left(\times 10^{3}\right)\end{array}$ & $\begin{array}{c}\text { Shell/River } \\
\text { waetr } \\
(\times 10)\end{array}$ & $\begin{array}{c}\text { Pearl/River } \\
\text { water } \\
(\times 10)\end{array}$ \\
\hline${ }^{57} \mathrm{La}$ & 10.9 & 9.03 & 20 & 3.3 \\
${ }^{58} \mathrm{Ce}$ & 63.1 & 41 & 120 & 18.3 \\
${ }^{59} \mathrm{Pr}$ & 32.9 & 11 & 24 & 5.3 \\
${ }^{60} \mathrm{Nd}$ & 11.6 & 8.3 & 19 & 3.4 \\
${ }^{62} \mathrm{Sm}$ & 15.9 & 8.3 & 25.3 & 10.3 \\
${ }^{63} \mathrm{Eu}$ & 14.4 & 6.1 & 21.4 & 15.7 \\
${ }^{64} \mathrm{Gd}$ & 10.4 & 4.9 & 12.7 & 5.0 \\
${ }^{65} \mathrm{~Tb}$ & 20.3 & 7.1 & 16.6 & 7.5 \\
${ }^{66} \mathrm{Dy}$ & 10.6 & 2.4 & 14.2 & 3.0 \\
${ }^{67} \mathrm{Ho}$ & 5.8 & 2.3 & 10.6 & 4.0 \\
${ }^{68} \mathrm{Er}$ & 6.0 & 1.7 & 8.2 & 2.8 \\
${ }^{69} \mathrm{Tm}$ & 3.6 & 1.3 & 7.2 & 3.3 \\
${ }^{70} \mathrm{Yb}$ & 7.16 & 13.8 & 6.4 & 32.2 \\
${ }^{71} \mathrm{Lu}$ & 4.26 & 3.4 & 10.0 & 8.8 \\
\hline
\end{tabular}

organic substance of shellfish plays a part in accumulation of lanthanoids into the hard tissue. And we considered that the difference between the concentration ratio of seawater to fresh water was due to difference of constituents in these water samples and in these kinds of shells.

In this study we mainly examined the methods to determine lanthanoids in hard tissue. In order to explain quantitatively the behavior of lanthanoids on the basis of data obtained, a considerable amount of shellfish is required and also further analysis of lanthanoids in environmental samples, and knowledge on distribution and circulation would be necessary. A thorough analysis on these matter is now being studied, and we are going to report the results at the next opportunity.
We are grateful for donation of Akoya-gai shells and pearls from the Ago Bay by Mr. Kazuo Takeuchi and the Lake Biwa Ikecho-gai by Mrs. Kiyoko Nakayama.

This study was supported by a 1995 annual grant of Kinki University.

\section{References}

1. D. McConnel, "Apatite", Springer-Verlag, New York, 1973.

2. O. Fujino, S. Umetani and M. Matsui, Anal. Chim. Acta, 296, 63 (1994).

3. O. Fujino, M. Matsui, S. Umetani and K. Hiraki, Nippon Kagaku Kaishi, 1989, 39.

4. O. Fujino, M. Matsui, T. Nagahiro, Y. Nakaguchi and K. Hiraki, Nippon Kagaku Kaishi, 1988, 153.

5. O. Fujino, Bull. Chem. Soc. Jpn., 48, 1455 (1975).

6. O. Fujino, T. Kumagai, T. Shigematsu and M. Matsui Bull. Chem. Res. Kyoto Univ., 54, 312 (1976).

7. E. D. Goldberg, M. Koide, R. A. Schmitt and R. H. Smith, J. Geophys. Res., 68, 4209 (1963).

8. N. E. Topp, "Chemistry of the Rare-Earth Elements", Elsevier, New York, 1965.

9. P. Henderson, "Rare Earth Elements Geochemistry", Elsevier, New York, 1965.

10. O. Fujino and T. Okuda, Nippon Kagaku Kaishi, 1993, 561.

11. H. Kawaguchi and T. Nakahara, "Plasma Source Mass Spectrometry", Gatsukai Syutsupan Center, Tokyo, 1994.

12. M. Nishimura, "Enviromental Chemistry", Shokabo, Tokyo, 1991.

13. G. Oddo, Z. Anorg. Chem., 87, 253 (1914).

14. W. D. Harkins, J. Amer. Chem. Soc, 39, 856 (1917).

15. H. Yanagida and T. Kanou, "Rare Earths", p. 129, Gihoudo, Tokyo, 1983. 